\title{
Inhibition of Low Density Lipoprotein-oxidation, ACAT-1, and ACAT-2 by Lignans from the Bark of Machilus thunbergii
}

\author{
Sabina Shrestha ${ }^{1}$, Ji-Hae Park ${ }^{1}$, Dae-Young Lee ${ }^{1}$, Jin-Gyeong Cho ${ }^{1}$, Do-Gyeong Lee ${ }^{1}$, \\ Moon-Hee Cho' ${ }^{2}$, Tae-Sook Jeong ${ }^{2}$, Hee-Cheol Kang ${ }^{3}$, and Nam-In Baek ${ }^{1 *}$ \\ ${ }^{1}$ Graduate School of Biotechnology, Institute of Life Sciences \& Resources, Kyung Hee University, \\ Yongin 446-701, Republic of Korea \\ ${ }^{2}$ Korea Research Institute of Bioscience \& Biotechnology, Daejeon 305-806, Republic of Korea \\ ${ }^{3} R \& D$ Center, Green Flower Cosmetics Co., Suwon 443-813, Republic of Korea
}

Received January 22, 2011; Accepted March 7, 2011

\begin{abstract}
The bark of Machilus thunbergii was extracted with $80 \%$ aqueous methanol $(\mathrm{MeOH})$, and the concentrated extract was partitioned using ethyl acetate (EtOAc), butanol ( $n$ - $\mathrm{BuOH})$, and $\mathrm{H}_{2} \mathrm{O}$, successively. From the EtOAc fraction, five lignans were isolated through the repeated silica gel, octadecyl silica gel (ODS) and, Sephadex LH-20 column chromatography. Based on nuclear magnetic resonance (NMR), mass spectroscopy (MS), and infrared spectroscopy (IR) spectroscopic data, the chemical structures of the compounds were determined to be machilin $A$ (1), machilin $F$ (2), licarin A (3), nectandrin A (4), and nectandrin B, (5). This study presents comparative account of five lignans from $M$. thunbergii bark contributing inhibition of low density lipoprotein (LDL), ACAT-1, and ACAT-2. Compounds 2-5 showed varied degree of antioxidant activity on LDL with $\mathrm{IC}_{50}$ values of $2.1,11.8,15.3$, and $4.1 \mu \mathrm{M}$. Compounds 1,2 , and 3 showed inhibition activity on ACAT-1 with values $63.4 \pm 6.9 \%\left(\mathrm{IC}_{50}=66.8 \mu \mathrm{M}\right), 53.7 \pm 0.9 \%\left(\mathrm{IC}_{50}=109.2 \mu \mathrm{M}\right)$, and $78.7 \pm 0.2 \%\left(\mathrm{IC}_{50}=\right.$ $40.6 \mu \mathrm{M}$ ), respectively, at a concentration of $50 \mathrm{mg} / \mathrm{mL}$, and on ACAT-2 with values $47.3 \pm 1.5 \%$ $\left(\mathrm{IC}_{50}=149.7 \mu \mathrm{M}\right), 39.2 \pm 0.2 \%\left(\mathrm{IC}_{50}=165.2 \mu \mathrm{M}\right)$, and $52.1 \pm 1.0 \%\left(\mathrm{IC}_{50}=131.0 \mu \mathrm{M}\right)$, respectively, at a concentration of $50 \mathrm{mg} / \mathrm{mL}$.
\end{abstract}

Key words: ACAT-1, ACAT-2, LDL-oxidation, licarin A, machilin A, machilin F, Machilus thunbergii, nectandrin $\mathrm{A}$, nectandrin $\mathrm{B}$

Machilus thunbergii Siebold \& Zuccarinii (Lauraceae) is a widely distributed tree used in Korean traditional medicine [Kim, 1984]. The cortex of the plant is used for treatment of leg edema, abdominal distension, and pain [Chung and Shin, 2000]. Several lignans and neolignans have been reported from the bark of this plant [Shimomura et al., 1987; 1988]. Previous studies on the bark of $M$. thunbergii reported nitric oxide synthesis inhibitory butanolides [Kim and Ryu, 2003]. Some lignans from the bark have been shown to be antioxidant [Yu et al., 2000], melanin biosysnthesis inhibitory [Li et al., 2003], caspase-3 activating [Park et al., 2004], and neuroprotective [Ma et al., 2004; 2009]. In this study we isolated 5 lignans and investigated on their inhibition effect on LDL-oxidation and ACAT-1 and ACAT-2 activities.

Oxidation of low-density lipoprotein (LDL) is considered as an early event in the development of atherosclerosis [Glass and Witztum, 2001]. Antioxidants such as probucol, N,N'-diphenyl

*Corresponding author

Phone: +82-31-201-2661; Fax: +82-31-204-8116

E-mail: nibaek@khu.ac.kr

doi:10.3839/jabc.2011.011 phenylenediamine, and butylated hydroxy-toluene (BHT) have been shown to decrease the degree of oxidation and the extent of atheromatous lesions in animal models of atherosclerosis, but have side effects [Jialal and Devaraj, 1996]. Thus antioxidants from natural source are attractive alternatives. Cholesterol acyltransferase (ACAT) catalyses the acylation of cholesterol to cholesteryl ester and it exists in two isoforms, ACAT-1 and ACAT-2. ACAT-1 is in charge of foam cell formation in macrophages, whereas ACAT-2 controls the cholesterol absorption in intestinal mucosal cells [Rudel et al., 2001]. Therefore, ACAT inhibition is a useful strategy for treating hypercholesterolemia and atherosclerosis by the effect of lowering plasma cholesterol in humans [Lawrence and Gregory, 2000].

The dried bark of $M$. thunbergii was received from Green Flower Cosmetics Co., in 2009 and was identified by Prof. DaeKeun Kim, College of Pharmacy, Woosuk University, Jeonju, Korea. A voucher specimen (KHU-090826) was deposited at the laboratory of Natural Products Chemistry, Kyung Hee University, Yongin, Korea. The dried and powdered bark of $M$. thunbergii $(500 \mathrm{~g})$ was extracted two times with $80 \%$ aqueous methanol $(\mathrm{MeOH})[4 \mathrm{~L}]$ at room temperature. The $\mathrm{MeOH}$ extract was successively partitioned with water (2 L), ethyl 
acetate $(\mathrm{EtOAc})[2 \mathrm{~L} \times 2]$, and $n$-butanol $(1 \mathrm{~L} \times 2)$. The concentrated EtOAc extract (MTE, $16 \mathrm{~g}$ ) was applied to a silica gel (Merck 60A, 70-230 mesh ASTM, Darmstadt, Germany) column chromatography (c.c.) $(\phi 6 \times 14 \mathrm{~cm})$ and was eluted with $\mathrm{CHCl}_{3^{-}}$ $\mathrm{MeOH}-\mathrm{H}_{2} \mathrm{O}(20: 3: 1 \rightarrow 17: 3: 1 \rightarrow 9: 3: 1 \rightarrow 6: 4: 1,6 \mathrm{~L}$ of each $)$ with monitoring by thin layer chromatography (TLC) to provide 20 fractions (MTE-1 to MTE-20).

Fraction MTE-2 [1.79 g, elution volume/total volume $\left(\mathrm{V}_{\mathrm{e}} / \mathrm{V}_{\mathrm{t}}\right)$ $0.006-0.009]$ was subjected to the silica gel c.c. $(\phi 4 \times 12 \mathrm{~cm})$ eluted with $n$-hexane-EtOAc $(10: 1 \rightarrow 5: 1,2.5 \mathrm{~L}$ of each), yielding 22 fractions (MTE-2-1 to MTE-2-22) and an isolated compound 1 [ $33 \mathrm{mg}, \mathrm{V}_{\mathrm{e}} / \mathrm{V}_{\mathrm{t}}$ 0.019-0.020, TLC $\left(\mathrm{SiO}_{2}\right) R_{f} 0.20, n$ hexane-EtOAc=10:1].

Subfraction MTE-2-17 (100 mg, $\mathrm{V}_{\mathrm{e}} / \mathrm{V}_{\mathrm{t}}$ 0.218-0.356) was subjected to an octadecyl silica gel (ODS) c.c. $(\phi 2.5 \times 2 \mathrm{~cm})$ and eluted with $n$-hexane-EtOAc-MeOH- $\mathrm{H}_{2} \mathrm{O}$ (4:2:4:2), yielding 5 fractions (MTE-2-17-1 to MTE-2-17-5). Then, MTE-2-17-3 (66 $\mathrm{mg})$ subjected to a Sephadex LH-20 c.c. $(\phi 2 \times 35 \mathrm{~cm})$ eluted with $n$-hexane-EtOAc-MeOH- $\mathrm{H}_{2} \mathrm{O} \quad(4: 2: 4: 2)$, yielding 5 fractions (MTE-2-17-3-1 to MTE-2-17-3-5). Further, MTE-2-17-3-3 (52 $\left.\mathrm{mg}, \mathrm{V}_{\mathrm{e}} / \mathrm{V}_{\mathrm{t}} 0.40-0.56\right)$ was applied to the ODS c.c. $(\phi 2 \times 2.5 \mathrm{~cm})$ eluted with $\mathrm{MeOH}-\mathrm{H}_{2} \mathrm{O}$ (5:4), yielding 7 fractions (MTE-2-173-3-1 to MTE-2-17-3-3-7) and ultimately isolated compound 2 [18 mg, $\mathrm{V}_{\mathrm{e}} / \mathrm{V}_{\mathrm{t}}$ 0.110-0.015, TLC (ODS $\mathrm{F}_{254 \mathrm{~S}}$ ) $R_{f} 0.47, \mathrm{MeOH}-$ $\left.\mathrm{H}_{2} \mathrm{O}=6: 1\right]$ and compound $3\left[19.5 \mathrm{mg}, \mathrm{V}_{\mathrm{e}} / \mathrm{V}_{\mathrm{t}}\right.$ 0.27-0.65, TLC $\left.\left(\mathrm{ODS} \mathrm{F}_{254 \mathrm{~S}}\right) R_{f} 0.42, \mathrm{MeOH}-\mathrm{H}_{2} \mathrm{O}=6: 1\right]$.

Subfraction MTE-2-21 (107.5 mg, $\mathrm{V}_{\mathrm{e}} / \mathrm{V}_{\mathrm{t}}$ 0.66-0.89) was applied to the ODS c.c. $(\phi 2.5 \times 4 \mathrm{~cm})$ eluted with $\mathrm{MeOH}-\mathrm{H}_{2} \mathrm{O}$ (4:1), yielding 18 fractions (MTE-2-22-1 to MTE-2-21-18) and ultimately isolated compound $4\left[25.5 \mathrm{mg}, \mathrm{V}_{\mathrm{e}} / \mathrm{V}_{\mathrm{t}}\right.$ 0.14-0.18, TLC $\left.\left(\mathrm{ODS} \mathrm{F}_{254 \mathrm{~S}}\right) R_{f} 0.55, \mathrm{MeOH}-\mathrm{H}_{2} \mathrm{O}=6: 1\right]$ and compound 5 [21.5 $\mathrm{mg}, \mathrm{V}_{\mathrm{e}} / \mathrm{V}_{\mathrm{t}}$ 0.08-0.10, TLC (ODS $\mathrm{F}_{254 \mathrm{~S}}$ ) $R_{f} 0.65, \mathrm{MeOH}-\mathrm{H}_{2} \mathrm{O}=$ 6:1].

Compound 1: Colourless needle; m.p. $48-50^{\circ} \mathrm{C} ;[\alpha]_{D}^{20}=5.50^{\circ}$ $\left(c=0.10, \mathrm{CHCl}_{3}\right)$; EI-MS $m / z 326[\mathrm{M}]^{+}$; IR $\left(\mathrm{CaF}_{2}\right.$ window, $\left.\mathrm{cm}^{-1}\right)$ 2905, 1600, 1505, 1450; ${ }^{1} \mathrm{H}-\mathrm{NMR}$ (400 $\left.\mathrm{MHz}, \mathrm{CDCl}_{3}, \delta\right) 6.72$ ( $\left.2 \mathrm{H}, \mathrm{d}, J=8.0 \mathrm{~Hz}, \mathrm{H}-5,5^{\prime}\right), 6.67$ (2H, br.s, H-2, 2'), 6.57 (2H, dd, $\left.J=8.0,1.6 \mathrm{~Hz}, \mathrm{H}-6,6^{\prime}\right), 5.90\left(4 \mathrm{H}, \mathrm{s}, \mathrm{OCH}_{2} \mathrm{O} \times 2\right), 2.70(2 \mathrm{H}, \mathrm{dd}$, $J=13.5,4.8 \mathrm{~Hz}, \mathrm{H}-7 \mathrm{~b}, 7 \mathrm{~b}$ ), 2.26 (2H, dd, $J=13.5,9.2 \mathrm{~Hz}, \mathrm{H}-7 \mathrm{a}$, 7'a), 1.75 (2H, m, H-8, 8'), 0.86 (6H, d, J=6.8 Hz, H-9, 9'); ${ }^{13} \mathrm{C}-$ NMR (100 MHz, $\left.\mathrm{CDCl}_{3}, \delta\right) 147.34$ (C-4, 4'), 145.35 (C-3, 3'), 135.50 (C-1, 1'), 121.72 (C-6, 6'), 109.23 (C-5, 5'), 107.87 (C-2, $\left.2^{\prime}\right), 100.64\left(\mathrm{OCH}_{2} \mathrm{O} \times 2\right), 39.43\left(\mathrm{C}-7,7^{\prime}\right), 39.05\left(\mathrm{C}-8,8^{\prime}\right), 16.18$ (C-9, 9').

Compound 2: Colorless oil; $[\alpha]_{D}^{20}=-46.10^{\circ}\left(c=0.10, \mathrm{CHCl}_{3}\right)$; EI-MS $m / z 342[\mathrm{M}]^{+}$; IR $\left(\mathrm{CaF}_{2}\right.$ window, $\left.\mathrm{cm}^{-1}\right)$ 3550, 2930, 1720, 1450, 1250; ${ }^{1} \mathrm{H}-\mathrm{NMR}\left(400 \mathrm{MHz}, \mathrm{CDCl}_{3}, \delta\right) 6.95(1 \mathrm{H}, \mathrm{d}$, $J=1.2 \mathrm{~Hz}, \mathrm{H}-2), 6.88$ (1H, d, $\left.J=1.2 \mathrm{~Hz}, \mathrm{H}-2)^{\prime}\right), 6.87$ (2H, dd, $\left.J=8.0,1.2 \mathrm{~Hz}, \mathrm{H}-6,6^{\prime}\right), 6.77$ (2H, d, $J=8.0 \mathrm{~Hz}, \mathrm{H}-5,5$ ') $5.93(2 \mathrm{H}$, s, $\left.\mathrm{OCH}_{2} \mathrm{O}\right), 5.61\left(1 \mathrm{H}, \mathrm{s}, \mathrm{OH}, \mathrm{H}-4^{\prime}\right), 4.44(2 \mathrm{H}, \mathrm{dd}, J=6.4,2.8 \mathrm{~Hz}$,
H-7, 7'), 3.87 (3H, s, $\left.\mathrm{OCH}_{3}\right), 2.26\left(2 \mathrm{H}, \mathrm{m}, \mathrm{H}-8,8^{\prime}\right), 1.00(6 \mathrm{H}, \mathrm{d}$, $\left.J=6.4 \mathrm{~Hz}, \mathrm{H}-9,9^{\prime}\right) ;{ }^{13} \mathrm{C}-\mathrm{NMR}\left(100 \mathrm{MHz}, \mathrm{CDCl}_{3}, \delta\right) 147.60$ (C3), 146.80 (C-4), 146.30 (C-3'), 144.84 (C-4'), 135.97 (C-1'), 133.81 (C-1), 119.80 (C-6'), 119.20 (C-6), 114.00 (C-5'), 108.80 (C-5), 107.88 (C-2'), 106.69 (C-2), $100.89\left(\mathrm{OCH}_{2} \mathrm{O}\right), 87.35$ (C7'), 87.25 (C-7), $55.82\left(\mathrm{OCH}_{3}\right), 44.53$ (C-8), 44.44 (C-8'), 12.94 (C-9), 12.93 (C-9').

Compound 3: Colourless crystals; m.p. $102-104^{\circ} \mathrm{C} ;[\alpha]_{D}^{20}=$ $-35.40^{\circ}\left(c=0.10, \mathrm{CHCl}_{3}\right)$; EI-MS $m / z 326[\mathrm{M}]^{+}$; IR $\left(\mathrm{CaF}_{2}\right.$ window, $\left.\mathrm{cm}^{-1}\right)$ 3400, 2957, 1608, 1510, 1480, 1210; ${ }^{1} \mathrm{H}-\mathrm{NMR}$ (400 MHz, $\left.\mathrm{CDCl}_{3}, \delta\right) 6.95$ (1H, br.s, H-2), 6.87 (1H, d, J=7.2 Hz, H-5), 6.85 (1H, br.d, J=7.2 Hz, H-6), 6.76 (1H, br.s, H-6'), 6.74 (1H, br.s, H-2'), 6.33 (1H, dd, $J=15.6,1.6, \mathrm{H}-7$ '), 6.08 (dq, $\left.J=15.6,6.8 \mathrm{~Hz}, \mathrm{H}-8^{\prime}\right), 5.65(1 \mathrm{H}, \mathrm{s}, \mathrm{OH}), 5.06(1 \mathrm{H}, \mathrm{d}, J=9.6 \mathrm{~Hz}$, $\mathrm{H}-7), 3.85\left(6 \mathrm{H}, \mathrm{s}, \mathrm{OCH}_{3} \times 2\right), 3.41(1 \mathrm{H}, \mathrm{dq}, J=9.6,6.8 \mathrm{~Hz}, \mathrm{H}-8)$, $1.84(3 \mathrm{H}, \mathrm{d}, J=6.8 \mathrm{~Hz}, \mathrm{C}-9$ '), 1.34 (3H, d, $J=6.8 \mathrm{~Hz}, \mathrm{C}-9) ;{ }^{13} \mathrm{C}-$ NMR (100 MHz, $\left.\mathrm{CDCl}_{3}, \delta\right) 146.56$ (C-3), 146.35 (C-4'), 145.61 (C-4), 143.95 (C-5'), 133.11 (C-3'), 132.04 (C-1'), 131.87 (C-1), 130.75 (C-7'), 123.37 (C-8'), 119.83 (C-6), 114.01 (C-5), 113.19 (C-2'), 109.06 (C-6'), 108.87 (C-2), 93.72 (C-7), $55.9\left(\mathrm{OCH}_{3} \times\right.$ 2), 45.60 (C-8), 18.42 (C-9'), 17.56 (C-9).

Compound 4: Colourless oil; $[\alpha]_{D}^{23}=-8.9^{\circ}\left(c=0.40, \mathrm{CHCl}_{3}\right)$; EI-MS $m / z 358[\mathrm{M}]^{+}$; IR $\left(\mathrm{CaF}_{2}\right.$ window, $\left.\mathrm{cm}^{-1}\right) 3540,2950,1610$, $1250 ;{ }^{1} \mathrm{H}-\mathrm{NMR}\left(400 \mathrm{MHz}, \mathrm{CDCl}_{3}, \delta\right) 6.95(1 \mathrm{H}, \mathrm{d}, J=1.6 \mathrm{~Hz}, \mathrm{H}-$ 2), $6.93(1 \mathrm{H}, \mathrm{d}, J=1.6 \mathrm{~Hz}, \mathrm{H}-2$ '), 6.94 (overlapped, H-6), 6.91 (1H, dd, $\left.J=8.0,1.6 \mathrm{~Hz}, \mathrm{H}-6^{\prime}\right), 6.87\left(1 \mathrm{H}, \mathrm{d}, J=8.0 \mathrm{~Hz}, \mathrm{H}-5^{\prime}\right), 6.83$ $(1 \mathrm{H}, \mathrm{d}, J=8.0 \mathrm{~Hz}, \mathrm{H}-5), 5.57$ (1H, s, HO-4), 4.49 (1H, d, $J=5.6$ Hz, H-7'), 4.48 (1H, d, J=5.6 Hz, H-7), $3.85\left(9 \mathrm{H}, \mathrm{s}, \mathrm{OCH}_{3} \times 3\right)$, $2.30\left(2 \mathrm{H}, \mathrm{m}, \mathrm{H}-8,8^{\prime}\right), 1.01\left(6 \mathrm{H}, \mathrm{d}, J=6.7 \mathrm{~Hz}, \mathrm{CH}_{3}-9,9^{\prime}\right) ;{ }^{13} \mathrm{C}-$ NMR (100 MHz, $\left.\mathrm{CDCl}_{3}, \delta\right) 148.79$ (C-3), 148.30 (C-4), 146.37 (C-3'), 144.94 (C-4'), 134.71 (C-1'), 134.07 (C-1), 119.21 (C-6'), 118.50 (C-6), 114.03 (C-5'), 110.71 (C-5), 109.52 (C-2), 109.00 (C-2'), 87.26 (C-7'), 87.16 (C-7), $55.80\left(\mathrm{OCH}_{3} \times 2\right), 44.30$ (C-8'), 44.26 (C-8), 12.96 (C-9'), 12.90 (C-9).

Compound 5: Colourless oil; $[\alpha]_{D}^{23}=0^{\circ}\left(c=0.4, \mathrm{CHCl}_{3}\right)$; EIMS $m / z 344[\mathrm{M}]^{+}$; IR $\left(\mathrm{CaF}_{2}\right.$ window, $\left.\mathrm{cm}^{-1}\right)$ 3390, 3050, 1640, 1590, 1240; ${ }^{1} \mathrm{H}-\mathrm{NMR}\left(400 \mathrm{MHz}, \mathrm{CDCl}_{3}, \delta\right) 6.91(2 \mathrm{H}, \mathrm{d}, J=1.6$ Hz, H-2, 2'), 6.87 (2H, dd, J=8.0, 1.6 Hz, H-6, 6'), 6.84 (2H, d, $\left.J=8.0 \mathrm{~Hz}, \mathrm{H}-5,5^{\prime}\right), 4.47$ (2H, d, J=6.4 Hz, H-7, 7'), 3.85 (6H, s, $\left.\mathrm{OCH}_{3} \times 2\right), 2.30\left(2 \mathrm{H}, \mathrm{m}, \mathrm{H}-8,8^{\prime}\right), 1.07\left(6 \mathrm{H}, \mathrm{d}, J=6.4 \mathrm{~Hz}, \mathrm{CH}_{3}-9\right.$, $\left.9^{\prime}\right) ;{ }^{13} \mathrm{C}-\mathrm{NMR}\left(100 \mathrm{MHz}, \mathrm{CDCl}_{3}, \delta\right) 146.24$ (C-3, 3'), 144.77 (C4, 4'), 133.93 (C-1, 1'), 119.09 (C-6, 6'), 113.97 (C-5', 5'), 108.97 (C-2, 2'), $87.24\left(\mathrm{C}-7,7^{\prime}\right), 55.80\left(\mathrm{OCH}_{3} \times 2\right), 44.25\left(\mathrm{C}-8,8^{\prime}\right), 12.99$ (C-9, 9').

LDL-oxidation assay was carried out using the method described in the literature [Lee et al., 2009], with BHT as a positive control. The activities of ACAT-1 and ACAT-2 were determined with the method developed by Brecher and Chan [1980] with slight modifications [Lee et al., 2001], with oleic acid anilide (OAA) as a positive control. The assay data are 
<smiles>CC(C)[C@@H](C)Cc1ccc2c(c1)OCO2</smiles>

1<smiles>C/C=C/c1ccc2c(c1)OC(c1ccc(O)c(OC)c1)[C@H]2C</smiles>

3<smiles>COc1cc([C@H]2OC3[C](c4ccc5c(c4)OCO5)[C@H](C2C)[C@H]3C)ccc1O</smiles>

2

4: $\mathrm{R}=\mathrm{CH}_{3}$

5: $\mathrm{R}=\mathrm{H}$

Fig. 1. Chemical structures of compounds 1-5 isolated from the bark of M. thunbergii.

Table 1. Inhibition activity of lignans from the bark of $M$. thunbergii on LDL-oxidation ${ }^{1}$, ACAT- ${ }^{2}$, and ACAT-2 ${ }^{3}$

\begin{tabular}{|c|c|c|c|c|c|c|c|c|}
\hline \multirow{2}{*}{ compounds } & \multicolumn{3}{|c|}{ LDL-oxidation Inhibition (\%) } & \multirow{2}{*}{$\mathrm{IC}_{50}(\mu \mathrm{M})$} & \multicolumn{2}{|c|}{ ACAT-1 Inhibition (\%) } & \multicolumn{2}{|c|}{ ACAT-2 Inhibition (\%) } \\
\hline & $10 \mu \mathrm{g} / \mathrm{mL}$ & $5 \mu \mathrm{g} / \mathrm{mL}$ & $2.5 \mu \mathrm{g} / \mathrm{mL}$ & & $50 \mu \mathrm{g} / \mathrm{mL}$ & $\mathrm{IC}_{50}(\mu \mathrm{M})$ & $50 \mu \mathrm{g} / \mathrm{mL}$ & $\mathrm{IC}_{50}(\mu \mathrm{M})$ \\
\hline 1 & $-16.9 \pm 2.6$ & N.D & N.D & - & $63.4 \pm 6.9$ & 66.8 & $47.3 \pm 1.5$ & 149.7 \\
\hline 2 & $97.6 \pm 0.1$ & 94.9 & $70.7 \pm 0.1$ & 2.1 & $53.7 \pm 0.9$ & 109.2 & $39.2 \pm 0.2$ & 165.2 \\
\hline 3 & $89.8 \pm 0.0$ & 70.0 & $26.3 \pm 1.2$ & 11.8 & $78.7 \pm 0.2$ & 40.6 & $52.1 \pm 1.0$ & 131.0 \\
\hline 4 & $96.1 \pm 0.5$ & 90.1 & $61.4 \pm 1.1$ & 15.3 & $16.7 \pm 1.7$ & - & $14.5 \pm 0.6$ & - \\
\hline 5 & $84.4 \pm 0.5$ & 40.1 & $11.0 \pm 1.9$ & 4.1 & $20.3 \pm 2.6$ & - & $13.0 \pm 0.7$ & - \\
\hline
\end{tabular}

Data are means \pm SD $(n=3)$.

${ }^{1}$ Positive control of LDL-Oxidation, BHT, showed $85.0 \pm 0.3 \%$ inhibition at $3.0 \mu \mathrm{M}$ with $\mathrm{IC}_{50}$ value of $2.1 \mu \mathrm{M}$.

${ }^{2}$ Positive control of ACAT-1, OAA, showed $33.6 \pm 1.5 \%$ inhibition at $0.1 \mu \mathrm{M}$ with $\mathrm{IC}_{50}$ value of $0.126 \mu \mathrm{M}$.

${ }^{3}$ Positive control of ACAT-2, OAA, showed $36.0 \pm 0.6 \%$ inhibition at $0.1 \mu \mathrm{M}$ with $\mathrm{IC}_{50}$ value of $0.138 \mu \mathrm{M}$.

expressed as mean \pm SD of three replicated experiments.

In a search of biologically active materials in M. thunbergii, the barks were extracted with $\mathrm{MeOH}$ and partitioned into EtOAc, $n-\mathrm{BuOH}$, and $\mathrm{H}_{2} \mathrm{O}$ layers through solvent fractionation. Successive repeated silica gel, ODS, and Sephadex LH-20 c.c. of the obtained fractions led to isolation of five lignans. Structural identifications of these lignans were determined to be machilin A (1), machilin F (2), licarin A (3), nectandrin A (4), and nectandrin $B(5)$ by interpretation of extensive spectroscopic data and comparison of data with those described in the literature [Shimomura et al., 1987; 1988; Lee et al., 2009] (Fig. $1)$.

The oxidation of LDL cholesterol is an important step in the formation of atherosclerotic lesions [Steinberg et al., 1989; Diaz et al., 1997]. Evidence to support this hypothesis is based in part on observation that demonstrate associations between oxidized LDL cholesterol and both the presence of atherosclerotic lesions [Regnstrom et al., 1992] and the progression of carotid artery atherosclerosis [Salonen et al., 1992]. In order to determine whether the compounds might be effective in the development of hypercholesterolemic or antiatherogenic agents, their potential for inhibiting LDL oxidation was evaluated. Compounds 2-5 showed varied degree of antioxidant activity with $\mathrm{IC}_{50}$ values of $2.1,11.8,15.3$, and $4.1 \mu \mathrm{M}$, respectively. The key factor governing the antioxidant activity is attributed to phenolic hydroxyl. Among these values compounds $\mathbf{2}$ and $\mathbf{5}$ showed significant inhibition in comparison to the positive control, BHT, which had an $\mathrm{IC}_{50}$ value $2.1 \mu \mathrm{M}$. Compounds $\mathbf{2}$ and $\mathbf{5}$ showed more potent activity than saururin ( $\left.\mathrm{IC}_{50} 8.5 \mu \mathrm{M}\right)$ and virolin $\left(\mathrm{IC}_{50} 4.3 \mu \mathrm{M}\right)$ from Saururus chinensis, the compound 2 was also more effective than machilin $\mathrm{D}\left(\mathrm{IC}_{50} 2.9 \mu \mathrm{M}\right)$, [Ahn et al., 2001]. This is first report of LDL oxidation activity for compounds 2-5. Compounds $\mathbf{1}, \mathbf{2}$, and $\mathbf{3}$ showed significant inhibitory activity on ACAT-1 with values of $63.4 \pm 6.9,53.7 \pm 0.9$, and $78.7 \pm 0.2 \%$, respectively, and on ACAT- 2 with values $47.3 \pm 1.5,39.2 \pm 0.2$, and $52.1 \pm 1.0 \%$, respectively, at a concentration $50 \mathrm{mg} / \mathrm{mL}$. The positive control OAA inhibited ACAT-1 by $36.6 \pm 1.5 \%$ and ACAT-2 by $36.0 \pm 0.6 \%$ at $0.1 \mu \mathrm{M}$ (Table1). Compounds $\mathbf{1}$ and $\mathbf{3}$ 
showed more potent activity than meso-dihydroguaiaretic acid from Myristica fragrans with ACAT $60.0 \pm 1.2 \%$ at concentration $100 \mathrm{mg} / \mathrm{mL}$ and compound 2 showed more potent activity than syringing methyl ether from $M$. fragrans with ACAT $27.2 \pm 0.9 \%$ at concentration $100 \mathrm{mg} / \mathrm{mL}$ [Song et al., 2004] and oleanolic acid from Albizia julibrissin with ACAT-1 $52.5 \pm 0.7 \%$ and ACAT-2 $22.0 \pm 2.6 \%$ at concentration $50 \mathrm{mg} / \mathrm{mL}$ [Baek et al., 2010]. This is first report of ACAT-1 and ACAT-2 inhibitory activity for compounds 1-5. Although compounds 1-5 had lower inhibition activity on ACAT-1 and ACAT-2 compared to positive control oleic acid anilide, the relative paucity of naturally occurring ACAT-1 and ACAT-2 inhibitors makes this report worth further investigation. There are few reports of LDLoxidation inhibitors, ACAT-1, and ACAT-2 from the natural resources. The compounds 2, 3, 4, and 5 exhibited similar activity for LDL-oxidation in comparison with the positive control. Compounds 1, 2, and $\mathbf{3}$ showed significant inhibitory activity on ACAT-1, and on ACAT-2. Therefore, the bark of $M$. thunbergii is used in oriental medicine in Korea can be useful source for treating hypercholesterolemia and atherosclerosis, and dementia. Among the active compounds, compound $\mathbf{2}$ appeared as the most potent inhibitor of LDL-oxidation with an $\mathrm{IC}_{50}$ value of $2.1 \mu \mathrm{M}$ and compound 3 as the most potent inhibitor of ACAT-1 and ACAT-2 with $\mathrm{IC}_{50}$ value of $40.6 \mu \mathrm{M}$ and 131.0 $\mu \mathrm{M}$, respectively.

Acknowledgments. This work was supported by a research grant (Project No. 2010-000360910210) funded by Small and Medium Business Administration (SMBA), Republic of Korea.

\section{References}

Ahn BT, Lee S, Lee SB, Lee ES, Kim JG, Bok SH, and Jeong TS (2001) Low-density lipoprotein-antioxidant constituents of Saururus chinensis. J Nat Prod 64, 1562-1564.

Baek MY, Cho JG, Lee DY, Ahn EM, Jeong TS, and Baek NI (2010) Isolation of triterpenoids from the stem bark of Albizia julibrissin and their inhibition activity on ACAT-1 and ACAT-2. J Korean Soc Appl Biol Chem 53, 310-315.

Brecher P and Chan CT (1980) Properties of acyl-CoA: cholesterol acyltransferase in aortic microsomes from atherosclerotic rabbits. Biochim Biophys Acta 617, 458-471.

Chung BS and Shin MG (2000) Dictionary of Korean Folk Medicine, Young Lim Sa, Seoul, Korea.

Diaz MN, Frei B, Vita JA, and Keaney JF (1997) Antioxidants and atherosclerotic heart disease. $N$ Engl J Med 337, 408-416.

Glass CK and Witztum JL (2001) Atherosclerosis: the road ahead. Cell 104, 501-516.

Jialal I and Devaraj S (1996) Low-density lipoprotein oxidation, antioxidants, and atherosclerosis: a clinical biochemistry perspective. Clin Chem 42, 498-506.

Kim JK (1984) Illustrated natural drugs encyclopedia, (Vol. 22). Namsandang, Seoul, Korea.
Kim NY and Ryu JH (2003) Butanolides from Machilus thunbergii and their inhibitory activity on nitric oxide synthesis in activated macrophages. Phytother Res 17, 372-375.

Lawrence LR and Gregory SS (2000) Cholesterol esters and atherosclerosis-a game of ACAT and mouse. Nat Med 6, 13411347.

Lee CH, Jeong TS, Choi YK, Hyun BW, Oh GT, Kim EH, Kin JR, Han JI, and Bok SH (2001) Anti-atherogenic effect of citrus flavonoids, maringin and naringenin associated with hepatic ACAT and aortic VCAM-1 and MCP-1 in high cholesterol-fed rabbits. Biochem Biophys Res Commun 284, 681-688.

Lee JK, Cho JG, Song MC, Yoo JS, Lee DY, Yang HJ, Han KM, Kim DH, Oh YJ, Jeong TS, and Baek NI (2009) Isolation of isoquinoline alkaloids from the tuber of Corydalis turtschaninovii and their inhibition activity on low density lipoprotein oxidation. $J$ Korean Soc Appl Biol Chem 52, 646-654.

Lee SU, Shim KS, Ryu SY, Min YK, and Kim SH (2009) Machilin A isolated from Myristica fragrans stimulates osteoblast differentiation. Planta Med 75, 152-157.

Li G, Ju HK, Chang HW, Jahng Y, Lee SH, and Son JK (2003) Melanin biosynthesis inhibitors from the bark of Machilus thunbergii. Biol Pharm Bull 26, 1039-1041.

Ma CJ, Kim YC, and Sung SH (2009) Compounds with neuroprotective activity from the medicinal plant Machilus thunbergii. J Enzy Inhib Med Ch 24, 1117-1121.

Ma CJ, Sung SH, and Kum YC (2004) Neuroprotective lignans from the bark of Machilus thunbergii. Planta Med 70, 79-80.

Park BY, Min BS, Kwon OK, Oh SR, Ahn KS, Kim TJ, Kim DY, Bae KW, and Lee HK (2004) Increase of Caspase-3 activity by lignans from Machilus thunbergii in HL-60 cells. Biol Pharm Bull 27, 1305-1307.

Regnstrom J, Nilsson J, Tornvall P, Landou C, and Hamsten A (1992) Susceptibility to low-density lipoprotein oxidation and coronary atherosclerosis in man. Lancet 339, 1183-1186.

Rudel LL, Lee RG, and Cockman TL (2001) Acyl coenzyme A: cholesterol acyltransferase types 1 and 2: structure and function in atherosclerosis. Curr Opin Lipidol 12, 121-127.

Salonen JT, Yla-Herttuala S, Yamamoto R, Butler S, Korpela H, Salonen R, Nyyssonen K, Palinski W, and Witztum JL (1992) Autoantibody against oxidised LDL and progression of carotid atherosclerosis. Lancet 339, 883-887.

Shimomura H, Sashida Y, and Oohara M (1987) Lignans from Machilus thunbergii. Phytochemistry 26, 1513-1515.

Shimomura H, Sashida Y, and Oohara M (1988) Lignans from Machilus thunbergii. Phytochemistry 27, 634-636.

Song MC, Ahn EM, Bang, MH, Kim SY, Rho YD, Kwon BM, Lee HS, and Baek NI (2004) Phenylpropanoids from Myristica fragans Houtt. J Korean Soc Appl Biol Chem 47, 366-369.

Steinberg D, Parthasarathy S, Carew TE, Khoo JC, and Witztum JL (1989) Beyond cholesterol. Modification of low density lipoprotein that increases its atherogenicity. $N$ Engl $J$ Med 320, 915-924.

Yu YU, Kang SY, Park HY, Sung SH, Lee EJ, and Kim YJ (2000) Antioxidant lignans from Machilus thunbergii protect $\mathrm{CCl}_{4}{ }^{-}$ injured primary cultures of rat hepatocytes. J Pharm Pharmacol 52, 1163-1169. 